\title{
Cupriavidus pampae sp. nov., a novel herbicide- degrading bacterium isolated from agricultural soil
}

\begin{abstract}
Correspondence
Edward R. B. Moore erbmoore@ccug.se
\end{abstract}

\author{
Virginia Cuadrado, ${ }^{1}$ Margarita Gomila, ${ }^{2}$ Luciano Merini, ${ }^{1}$ Ana M. Giulietti ${ }^{1}$ \\ and Edward R. B. Moore ${ }^{3,4}$
${ }^{1}$ Cátedra de Microbiología Industrial y Biotecnología, Facultad de Farmacia y Bioquímica, Universidad de Buenos Aires, Argentina d'Estudis Avançats (CSIC-UIB), 07122 Palma de Mallorca, Illes Balears, Spain
${ }^{3}$ Culture Collection University of Gothenburg (CCUG), Department of Clinical Bacteriology, Sahlgrenska University Hospital, Gothenburg, Sweden
${ }^{4}$ Sahlgrenska Academy of the University of Gothenburg, Gothenburg, Sweden \\ ${ }^{2}$ Microbiologia, Departament de Biologia, Universitat de les Illes Balears, and Institut Mediterrani
}

\begin{abstract}
A bacterial consortium able to degrade the herbicide 4-(2,4-dichlorophenoxy) butyric acid (2,4DB) was obtained from an agricultural soil of the Argentinean Humid Pampa region which has a history of long-term herbicide use. Four bacterial strains were isolated from the consortium and identified as members of the genera Cupriavidus, Labrys and Pseudomonas. A polyphasic systematic analysis was carried out on strain $\mathrm{CPDB}^{\top}$, the member of the 2,4-DB-degrading consortium able to degrade 2,4-DB as a sole carbon and energy source. The Gram-negative, rodshaped, motile, non-sporulating, non-fermenting bacterium was shown to belong to the genus Cupriavidus on the basis of $16 \mathrm{~S}$ rRNA gene sequence analyses. Strain $\mathrm{CPDB}^{\top}{ }^{\top}$ did not reduce nitrate, which differentiated it from the type species of the genus, Cupriavidus necator; it did not grow in $0.5-4.5 \% \mathrm{NaCl}$, although most species of Cupriavidus are able to grow at $\mathrm{NaCl}$ concentrations as high as $1.5 \%$; and it was able to deamidate acetamide, which differentiated it from all other species of Cupriavidus. DNA-DNA hybridization data revealed low levels of genomic DNA similarity (less than $30 \%$ ) between strain $\mathrm{CPDB}^{\top}$ and the type strains of Cupriavidus species with validly published names. The major cellular fatty acids detected were cis-9-hexadecenoic $(16: 1 \omega 7 c)$ and hexadecanoic $(16: 0)$ acids. On the basis of phenotypic and genotypic characterizations, strain $\mathrm{CPDB}^{\top}{ }^{\top}$ was recognized as a representative of a novel species within the genus Cupriavidus. The name Cupriavidus pampae sp. nov. is proposed, with strain CPDB6 $^{\top}\left(=\right.$ CCUG $\left._{55948^{\top}}=\mathrm{CCM}^{-A}-29: 1289^{\top}\right)$ as the type strain.
\end{abstract}

Phenoxy herbicides are employed widely in agricultural fields throughout the world for controlling broad leaf weeds in alfalfa, maize, peanut, soybean and other important crops and pastures. The extensive use of these pesticides causes some degree of concern due to contamination of the soil and

Abbreviations: 2,4-D, 2,4-dichlorophenoxyacetic acid; 2,4-DB, 4-(2,4dichlorophenoxy) butyric acid; 2,4-DCP, 2,4-dichlorophenol; AHP, Argentinean Humid Pampa; CC, Colón control; CPDB, Colón pasture 2,4-DB-treated; MPN, most-probable number.

The GenBank/EMBL/DDBJ accession numbers for the 16S rRNA gene sequences of strain $\mathrm{CPDB6}^{\top}$, C. basilensis CCUG $49340^{\top}$, C. laharis CCUG 53908 ${ }^{\top}$, C. oxalaticus CCUG $2086^{\top}$ and C. pinatubonensis CCUG 53907 ${ }^{\top}$ are FN430567, FN597608, FN597609, FN597610 and FN597611, respectively.

Cellular fatty acid data for strain $\mathrm{CPDB}^{\top}$ and type strains of the most closely related species of the genus Cupriavidus are available with the online version of this paper. non-target sites, such as groundwater and surface water courses (US EPA, 1992; Johannesen \& Aamand, 2003; EWG, 2006). The potential threat to the environment and human health, through possible carcinogenicity (classified as $2 \mathrm{~b}$; IARC, 2003) (Gosselin et al., 1984; Schop et al., 1990; Zahm et al., 1990), as well as gastrointestinal, liver, reproductive and developmental toxicities, is well documented (Stevens \& Sumner, 1991; Walker \& Keith, 1992; Weed Science Society of America, 1994; HSDB, 2005).

The Argentinean Humid Pampa (AHP) is one of the most productive agricultural areas in South America, and phenoxy herbicides, such as 2,4-dichlorophenoxyacetic acid (2,4-D) and 4-(2,4-dichlorophenoxy) butyric acid $(2,4-\mathrm{DB})$, are used frequently (INDEC, 2002). The dissipation of 2,4-D and 2,4-DB in high-humic-mattercontaining soils from the AHP has been studied in microcosm systems (Merini et al., 2007; Cuadrado et al., 
2008). When evaluating 2,4-DB biodegradation, a soil with a long-term history of herbicide use exhibited higher degradation rates in comparison with pristine soils, and a most-probable number (MPN) of $1 \times 10^{5} 2,4$-DB-degrading bacteria per gram of soil after 14 days in a microcosm with an application of 500 p.p.m. 2,4-DB (Cuadrado et al., 2008). Microcosm soils, with and without histories of herbicide use, were sampled to isolate micro-organisms responsible for the degradation of 2,4-DB. Two bacterial consortia able to degrade 2,4-DB were obtained and further characterized. Phenotypic and genotypic analyses revealed bacteria belonging to the genera Labrys and Pseudomonas in the 2,4-DB-degrading consortium obtained from the microcosm of pristine soil and strains belonging to the genera Labrys, Pseudomonas and Cupriavidus in the consortium from microcosms of long-term herbicide-treated soil. Strain $\mathrm{CPDB}^{\mathrm{T}}{ }^{\mathrm{T}}$ was a member of the 2,4 -DB-degrading consortium, enriched from the chronic herbicideexposed soil. Strain $\mathrm{CPDB}^{\mathrm{T}}$ was identified as belonging to the genus Cupriavidus by $16 \mathrm{~S}$ rRNA gene sequencing.

The genus Ralstonia was proposed in 1995 to accommodate the misplaced species Burkholderia pickettii, Burkholderia solanacearum and Alcaligenes eutrophus (Yabuuchi et al., 1995). The species classified in the genus Ralstonia were divided into species of Ralstonia (sensu stricto) and species of the novel genus Wautersia, with Wautersia eutropha as the type species (Vaneechoutte et al., 2004). Subsequently, Vandamme \& Coenye (2004) reported the genus name Wautersia to be a later synonym of Cupriavidus and proposed that all species of Wautersia be reclassified as Cupriavidus, with Cupriavidus necator as the type species. The genus Cupriavidus currently comprises 11 species derived from diverse ecological niches (Coenye et al., 2003). Strains of Cupriavidus species have been isolated from environmental and human clinical sources. C. necator (Makkar \& Casida, 1987), Cupriavidus oxalaticus (Sahin et al., 2000), Cupriavidus basilensis (Steinle et al., 1999), Cupriavidus campinensis (Goris et al., 2001), Cupriavidus metallidurans (Goris et al., 2001), Cupriavidus pinatubonensis and Cupriavidus laharis (Sato et al., 2006) were isolated initially from environmental sources and several strains of the species have been recognized as potential agents for bioremediation of soil and water contaminated with heavy metals or chlorinated organic compounds (Steinle et al., 1998; Goris et al., 2001; Vandamme \& Coenye, 2004). Other species, such as Cupriavidus gilardii, Cupriavidus pauculus, Cupriavidus respiraculi and Cupriavidus taiwanensis, have been isolated from both human clinical samples and environmental sources (Coenye et al., 1999; Vandamme et al., 1999; Chen et al., 2001; Wauters et al., 2001).

This report presents a systematic polyphasic analysis of strain $\mathrm{CPDB6}^{\mathrm{T}}$, a member of a 2,4-DB-degrading consortium, isolated from a herbicide-contaminated soil of the AHP region. Strain CPDB6 ${ }^{\mathrm{T}}\left(=\right.$ CCUG $55948^{\mathrm{T}}=$ CCM-A$29: 1289^{\mathrm{T}}$ ) represents a novel species of the genus Cupriavidus, for which the name Cupriavidus pampae sp. nov. is proposed.
Soil samples were collected from agricultural fields located in the proximity of Colón City in the AHP region $\left(33^{\circ} 52^{\prime}\right.$ $\left.23.33^{\prime \prime} \mathrm{S} 61^{\circ} 08^{\prime} 10.61^{\prime \prime} \mathrm{W}\right)$. The land was planted with a mixed pasture (alfalfa and other pasture species) and the soil, designated Colón Pasture 2,4-DB-treated (CPDB) soil, had a 20-year history of treatment with phenoxy herbicides (2,4-DB ester; $\left.100 \% ; 0.51 \mathrm{ha}^{-1}\right)$. The control soil, Colón control (CC), was sampled from a wild pasture and had never received herbicide application.

Microcosms of CPDB soil amended with 500 p.p.m. 2,4-DB exhibited an increase in 2,4-DB-degrading bacteria of five orders of magnitude in MPNs after 14 days (from nondetectable numbers at time 0 up to $2 \times 10^{5}$ MPN degrading bacteria per $\mathrm{g}$ dry soil) and $90 \%$ degradation of the herbicide by day 28 (Cuadrado et al., 2008). Samples ( $5 \mathrm{~g}$ ) from microcosms of CPDB and CC soils were used as inocula for enrichment cultures in a mineral medium containing $\left(1^{-1}\right)$ : $0.5 \mathrm{~g} 2,4-\mathrm{DB}$ as the sole source of carbon; $50 \mathrm{mg}$ cycloheximide as inhibitor of fungal growth; $0.5 \mathrm{~g} \mathrm{~K}_{2} \mathrm{HPO}_{4} ; 0.5 \mathrm{~g}$ $\left(\mathrm{NH}_{4}\right)_{2} \mathrm{SO}_{4} ; 0.5 \mathrm{~g} \quad \mathrm{MgSO}_{4} .7 \mathrm{H}_{2} \mathrm{O} ; 15 \mathrm{mg} \quad \mathrm{FeCl}_{3} .6 \mathrm{H}_{2} \mathrm{O}$; $11.4 \mathrm{mg} \quad \mathrm{CaCl}_{2} \cdot 2 \mathrm{H}_{2} \mathrm{O} ; \quad 0.16 \mathrm{mg} \quad \mathrm{MnCl}_{2} .4 \mathrm{H}_{2} \mathrm{O}$; and $0.018 \mathrm{mg} \mathrm{ZnSO}{ }_{4} \cdot 7 \mathrm{H}_{2} \mathrm{O}$. Cultures were incubated at $25^{\circ} \mathrm{C}$, with shaking at 200 r.p.m., and subcultured several times in the same medium, after confirmation of 2,4-DB dissipation by HPLC analysis.

A consortium obtained from soil with a history of herbicide application (CPDB) was able to grow in liquid culture with 2,4-DB as sole carbon source. Consortium CPDB exhibited $50 \%$ removal of the herbicide (initial concentration of 350 p.p.m.) after 6 days. Consortium $\mathrm{CPDB}$ was characterized further by analysing growth kinetics and catabolic performance. Bacterial members of the CPDB consortium were isolated by subculture on 2,4DB mineral medium and purification on R2A agar medium (Reasoner \& Geldreich, 1985). Four bacterial strains were isolated from the CPDB soil consortium and characterized with respect to 2,4-DB and 2,4-D degradation in liquid culture, as well as phenotypically and genotypically. Strain $\mathrm{CPDB6}^{\mathrm{T}}$ was selected for detailed characterization as a member of the CPDB consortium that was essential for herbicide degradation.

Strain $\mathrm{CPDB}^{\mathrm{T}}$ was cultured in liquid mineral medium with 2,4-DB or 2,4-D as the sole carbon source at a concentration range of $100-350$ p.p.m. Cultivation was carried out in triplicate, at $30{ }^{\circ} \mathrm{C}$, with shaking at 200 r.p.m., for 1 month, with controlled evaporation. Samples were taken periodically to measure bacterial biomass and the residual concentrations of the herbicides $2,4-\mathrm{DB}$ or $2,4-\mathrm{D}$, as well as the appearance of the intermediate metabolite 2,4-dichlorophenol (2,4DCP). Microbial biomass was estimated by spectrophotometric measurements of turbidity at $600 \mathrm{~nm}$. Assessments of 2,4-DB and metabolites 2,4-D and 2,4-DCP were performed using previously optimized HPLC analyses (Merini et al., 2008). Strain $\mathrm{CPDB6}^{\mathrm{T}}$, growing in mineral medium with $2,4-$ $\mathrm{DB}$ as the sole carbon source (350 p.p.m.), was able to degrade $22 \%$ of the herbicide after 25 days (Fig. 1). 


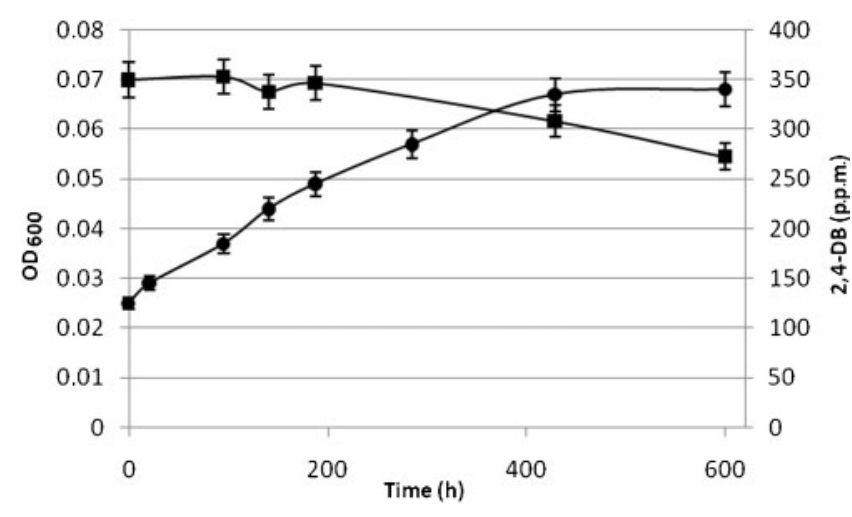

Fig. 1. Microbial growth and degradation of 2,4-DB herbicide by strain CPDB6 $^{\top}$ in liquid culture. $\bullet, O D$ at $600 \mathrm{~nm} ; \mathbf{\square}, 2,4-\mathrm{DB}$ (p.p.m.). Bars, $1 \mathrm{SD}(n=3)$.

After 4 days of incubation, colonies of strain $\mathrm{CPDB}^{\mathrm{T}}$ growing on R2A agar medium were $3-4 \mathrm{~mm}$ in diameter, non-pigmented, darker in the centre with a translucent and undulating margin. Strain $\mathrm{CPDB}^{\mathrm{T}}$ grew well on R2A agar medium at 10,22 and $30{ }^{\circ} \mathrm{C}$, and showed good growth on blood agar medium (Columbia agar base plus $5 \%$ defibrinated horse blood) at $30{ }^{\circ} \mathrm{C}$. Strain $\mathrm{CPDB}^{\mathrm{T}}$ showed weak growth on blood agar at $37^{\circ} \mathrm{C}$ and was not able to grow at $42{ }^{\circ} \mathrm{C}$. It stained Gram-negative, exhibited rodshaped, motile, non-sporulating, non-fermenting cells and was positive for catalase and oxidase. Strain $\mathrm{CPDB}^{\mathrm{T}}$ assimilated adipate, gluconate, malate, lactate and lactate + methionine. It was weakly positive for glucose and citrate assimilation and it was urease-negative. Strain $\mathrm{CPDB6}^{\mathrm{T}}$ did not reduce nitrate, which differentiated it from $C$. necator, the type species of the genus. It did not grow in $0.5-4.5 \% \mathrm{NaCl}$, although most species of Cupriavidus are able to grow at $\mathrm{NaCl}$ concentrations as high as $1.5 \%$. The ability of strain $\mathrm{CPDB}^{\mathrm{T}}$ to deamidate acetamide differentiated it from all other species of Cupriavidus. The phenotypic profile of strain $\mathrm{CPDB}^{\mathrm{T}}$, in comparison with the type strains of all species of Cupriavidus, was determined using the tests listed in the NFX phenotyping worksheet for Gram-negative, aerobic, non-fermenting bacilli (www.ccug.se/default.cfm?navID= 160), including the API 20NE and API ZYM test panels according to the instructions of the manufacturer (bioMérieux). Prior to analysis, strains were cultivated on the same medium (blood agar) under the same cultivation conditions (aerobic, $37{ }^{\circ} \mathrm{C}$ ) and tests were carried out using standardized protocols; quality controls were done according to the recommendations of the Swedish Board for Accreditation and Conformity Assessment (SWEDAC). Differential phenotypic features of strain $\mathrm{CPDB}^{\mathrm{T}}$ and the type strains of all species of Cupriavidus with validly published names are shown in Table 1; results of all tests can be seen under the entry for strain $\mathrm{CPDB}^{\mathrm{T}}$ (=CCUG $55948^{\mathrm{T}}$ ) at the CCUG website (www.ccug.se).
Genomic DNA from strain $\mathrm{CPDB6}^{\mathrm{T}}$, as well as from reference strains used for comparisons, was extracted from cell biomass collected from agar medium, suspended in $100 \mu \mathrm{l}$ TE buffer (10 mM Tris, $0.1 \mathrm{mM}$ EDTA, $\mathrm{pH}$ 8.0) and $15 \mu \mathrm{l}\left(0.05 \mathrm{U} \mathrm{ml}^{-1}\right)$ lysostaphin (Sigma), and incubated at $37{ }^{\circ} \mathrm{C}$ for $30 \mathrm{~min}$. Proteinase K (Sigma) $[10 \mu \mathrm{l}$

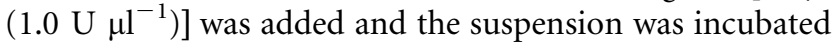
at $56{ }^{\circ} \mathrm{C}$ for $30 \mathrm{~min}$. After a subsequent $10 \mathrm{~min}$ incubation at $95{ }^{\circ} \mathrm{C}$, the suspension was centrifuged at $18000 \mathrm{~g}$ for $10 \mathrm{~min}$. The supernatant containing the bacterial DNA was separated and stored at $-20{ }^{\circ} \mathrm{C}$ until use. The $16 \mathrm{~S}$ rRNA gene was amplified from genomic DNA by PCR using primers 16F27 and 23R458 (Hernández et al., 2008), hybridizing at positions 9-27 and 458-473 of the $16 \mathrm{~S}$ and 23S rRNA gene sequence positions (Escherichia coli gene sequence nucleotide numbering), respectively. PCRs were carried out in duplicate $25 \mu \mathrm{l}$ reaction volumes; PCR products from duplicate reactions were combined, purified (QIAquick PCR purification kit; Qiagen) and sequenced directly using the methods (BigDye Terminator v3.1 Cycle Sequencing kit and the Prism 3100-Avant Genetic Analyzer; Applied Biosystems) and oligonucleotide primers described previously (Hauben et al., 1997). The nearly complete 16S rRNA gene sequence of strain $\mathrm{CPDB}^{\mathrm{T}}$ was determined (1504 nt positions; estimated $98.2 \%$ of the complete gene). The $16 \mathrm{~S}$ rRNA gene sequence of $\mathrm{CPDB} 6^{\mathrm{T}}$ was aligned and compared with sequences of the type strains of all species of the genus Cupriavidus with validly published names using the CLUSTAL_X software package (Thompson et al., 1997). Reference sequences used for comparative analyses were obtained from GenBank/EMBL (www.ebi.ac.uk/embl/), except for those of C. basilensis CCUG $49340^{\mathrm{T}}$, C. laharis CCUG $53908^{\mathrm{T}}$, C. oxalaticus CCUG $2086^{\mathrm{T}}$ and C. pinatubonensis CCUG $53907^{\mathrm{T}}$, which were determined in this study. A uniform sequence length of $1320 \mathrm{nt}$ positions (corresponding to positions 62-1385 of the E. coli $16 \mathrm{~S}$ rRNA gene sequence) was applied for determinations of sequence similarities, and phylogenetic relationships were calculated using the PHYLIP v. $3.5 \mathrm{c}$ (Felsenstein, 1989). The sequences of the type strains of Ralstonia pickettii (the type species of Ralstonia) and Ralstonia solanacearum were included in the analyses as an outgroup. Sequence similarities between the 16S rRNA gene sequence of strain $\mathrm{CPDB}^{\mathrm{T}}$ and those of the type strains of Cupriavidus species ranged from $98.3 \%$ (Cupriavidus respiraculi $\mathrm{AU} 3313^{\mathrm{T}}$ ) to a low similarity of $96.6 \%$ (C. laharis CCUG $53908^{\mathrm{T}}$ ) (Table 2). These sequence similarity values are within the range of $16 \mathrm{~S}$ rRNA gene sequence similarities observed between the type strains of the species of Cupriavidus (98.9\% between C. pauculus and C. metallidurans to $95.7 \%$ between $C$. metallidurans and C. laharis). A comparison of the $16 \mathrm{~S}$ rRNA gene sequence of $\mathrm{CPDB}^{\mathrm{T}}$ with those of type strains of the species of Cupriavidus indicated that strain $\mathrm{CPDB}^{\mathrm{T}}$ probably represents a novel species of the genus. Reconstructions of estimated phylogenetic relationships (Felsenstein, 1981) based on 16S rRNA gene sequence comparisons indicated that $\mathrm{CPDB}^{\mathrm{T}}$ was most closely 
Table 1. Phenotypic features differentiating strain $\mathrm{CPDB}^{\top}$ and the type strains of the species of the genus Cupriavidus

Strains: 1, strain CPDB6 ${ }^{\mathrm{T}}$; 2, C. necator CCUG $52238^{\mathrm{T}}$; 3, C. basilensis CCUG $49340^{\mathrm{T}}$; 4, C. campinensis CCUG 44526 $6^{\mathrm{T}}$; , C. gilardii CCUG $38401^{\mathrm{T}}$; 6, C. laharis CCUG 53908 ${ }^{\mathrm{T}}$; 7, C. metallidurans CCUG $13724^{\mathrm{T}}$; 8, C. oxalaticus CCUG $2086^{\mathrm{T}}$; 9, C. pauculus CCUG 12507 ${ }^{\mathrm{T}}$; 10 , C. pinatubonensis CCUG $53907^{\mathrm{T}}$; 11, C. respiraculi CCUG $46809^{\mathrm{T}}$; 12, C. taiwanensis CCUG $44338^{\mathrm{T}}$. -, Negative; $(+)$, weakly positive; + , positive; ND, not determined. Complete results of all phenotypic tests done on all strains can be found under the respective strain entry at www.ccug.se.

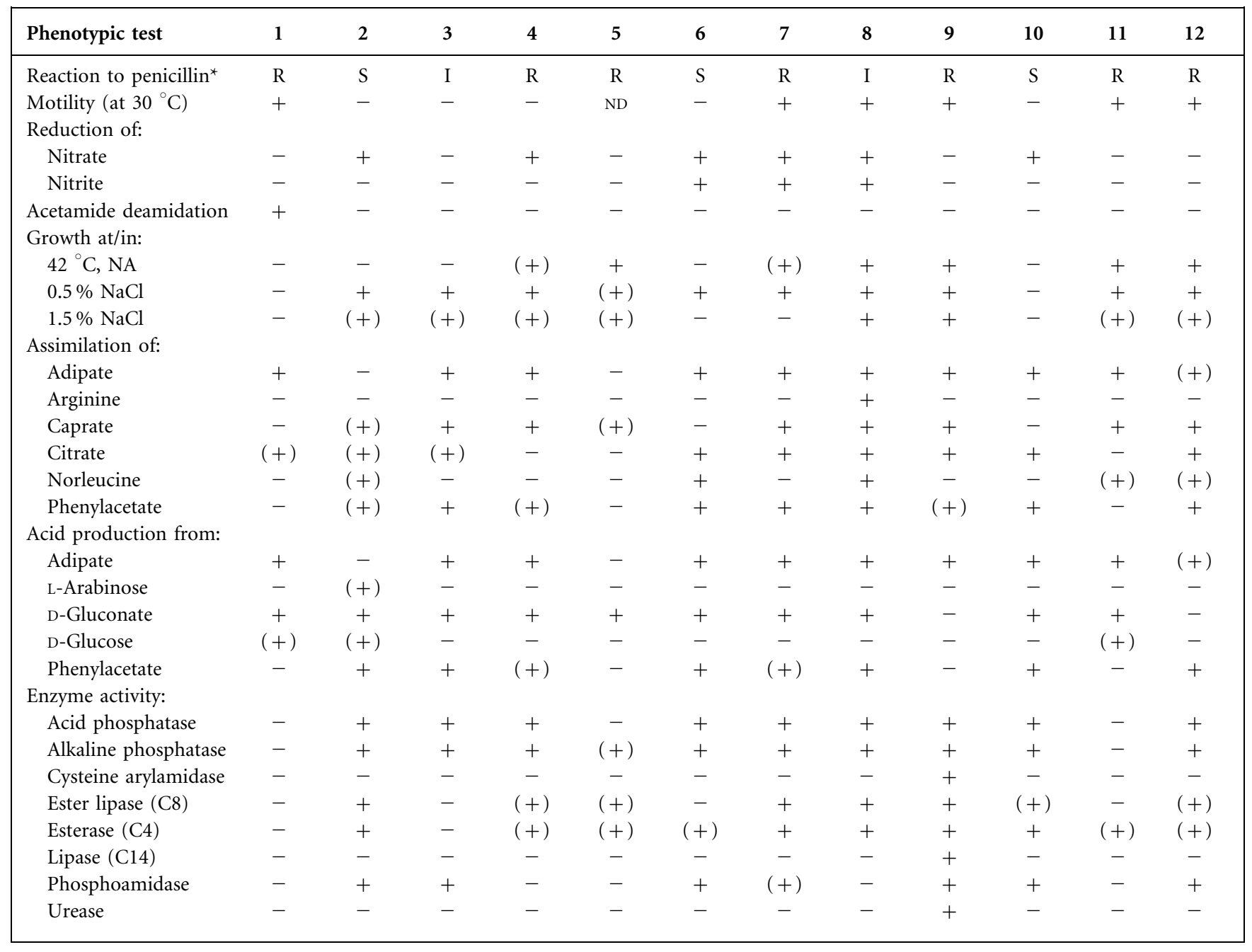

${ }^{*}$ Penicillin sensitivity: $\mathrm{R},<10 \mathrm{~mm}$ zone; $\mathrm{I}, 11-20 \mathrm{~mm}$ zone; $\mathrm{S},>20 \mathrm{~mm}$ zone.

related to C. gilardii, C. pauculus, C. respiraculi and C. metallidurans (Fig. 2). Alternative analyses of the sequence data were carried out using different algorithms (DNA neighbour-joining, DNA parsimony and DNA FitchMargoliash) and all analyses supported the phylogenetic position of $\mathrm{CPDB}^{\mathrm{T}}$ within the genus Cupriavidus. The reconstructions of phylogenetic relationships by all algorithms used indicated that the genus Cupriavidus comprises at least three phylogenetic 'lineages': 'lineage' 1, including species related to $C$. necator (the type species of the genus); 'lineage' 2 , including $\mathrm{CPDB}^{\mathrm{T}}$ and other species related to $C$. metallidurans; and 'lineage' 3 , including $C$. campinensis (Fig. 2). Comparisons of the 16S rRNA gene sequence of $\mathrm{CPDB}^{\mathrm{T}}$ with sequences deposited in the public databases using the FASTA-nucleotide matching tool
(Pearson \& Lipman, 1988) further suggested that strain $\mathrm{CPDB}^{\mathrm{T}}{ }^{2}$ represents a bacterium that may not have been recognized or isolated previously. The most similar $16 \mathrm{~S}$ rRNA gene sequences of organisms included within the GenBank/EMBL Prokaryote and the GenBank/EMBL Environmental databases comprised sequences from bacterial isolates and sequences from environmental samples (i.e. cloned DNA), respectively, and showed similarities of less than $99.0 \%$ to that of strain $\mathrm{CPDB}^{\mathrm{T}}$.

As the similarities between the 16S rRNA gene sequences of strain $\mathrm{CPDB6}^{\mathrm{T}}$ and the type strains of most species of Cupriavidus were greater than $97.0 \%$ (Stackebrandt \& Goebel, 1994; Table 2), DNA-DNA hybridizations were performed in duplicate using a non-radioactive method, as 
Table 2. $16 \mathrm{~S}$ rRNA gene sequence similarities and genomic DNA-DNA similarities between Cupriavidus sp. $\mathrm{CPDB}^{\top}$ and the type strains of species of Cupriavidus

Pooled standard deviations of all hybridization experiments were between 0.4 and 1.8 .

\begin{tabular}{|c|c|c|c|}
\hline \multirow[t]{2}{*}{ Cupriavidus spp. strains } & \multirow{2}{*}{$\begin{array}{l}\text { 16S rRNA gene sequence } \\
\text { similarities with CPDB6 }\end{array}$} & \multicolumn{2}{|c|}{ DNA-DNA hybridization values with: } \\
\hline & & $\mathrm{CPDB6}^{\mathrm{T}}$ & C. metallidurans CCUG $13724^{\mathrm{T}}$ \\
\hline 1. CPDB6 $^{\mathrm{T}}$ CCUG $55948^{\mathrm{T}}$ & 100 & 100 & 18 \\
\hline 2. C. necator CCUG $52238^{\mathrm{T}}$ & 97.8 & 13 & 12 \\
\hline 3. C. basilensis CCUG $49340^{\mathrm{T}}$ & 97.3 & 15 & 20 \\
\hline 4. C. campinensis CCUG $44526^{\mathrm{T}}$ & 97.6 & 29 & 41 \\
\hline 5. C. gilardii CCUG $38401^{\mathrm{T}}$ & 98.1 & 10 & 11 \\
\hline 6. C. laharis CCUG $53908^{\mathrm{T}}$ & 96.6 & 16 & 23 \\
\hline 7. C. metallidurans CCUG $13724^{\mathrm{T}}$ & 97.7 & 15 & 100 \\
\hline 8. C. oxalaticus CCUG $2086^{\mathrm{T}}$ & 97.8 & 20 & 25 \\
\hline 9. C. pauculus CCUG $12507^{\mathrm{T}}$ & 98.2 & 14 & 24 \\
\hline 10. C. pinatubonensis CCUG $53907^{\mathrm{T}}$ & 97.2 & 15 & 31 \\
\hline 11. C. respiraculi CCUG $46809^{\mathrm{T}}$ & 98.3 & 12 & 14 \\
\hline 12. C. taiwanensis CCUG $44338^{\mathrm{T}}$ & 97.5 & 15 & 27 \\
\hline
\end{tabular}

described previously in detail (Urdiain et al., 2008), with genomic DNAs isolated and purified according to the method of Marmur (1961). The DNAs of strain CPDB6 ${ }^{\mathrm{T}}$ and C. metallidurans CCUG $13724^{\mathrm{T}}$ were labelled with DIG-11-dUTP and Biotin-16-dUTP using a Nick Translation kit (Boehringer). Each labelled DNA was

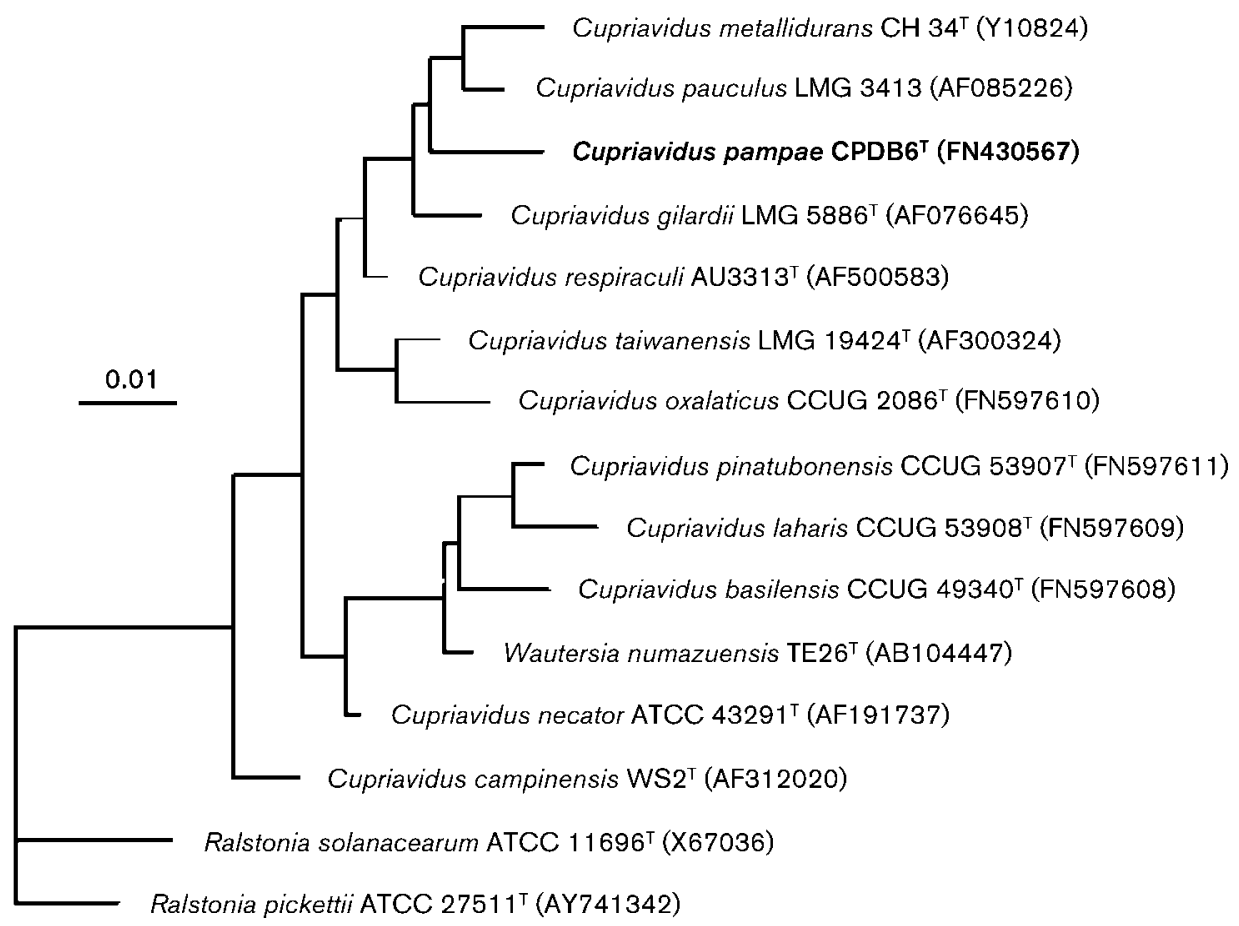

Fig. 2. Dendrogram of estimated phylogenetic relationships between strain Cupriavidus sp. CPDB6 ${ }^{\top}$ and the species of Cupriavidus based on 16S rRNA gene sequence comparisons of 1320 aligned nucleotide positions. The dendrogram was constructed using the DNA maximum-likelihood method (Felsenstein, 1981). Tree topology was visualized using the program TreeView (Page, 1996). Bootstrap values greater than 500, based on 1000 replications, are indicated at branching nodes. Bar, 0.01 nt substitutions per site. 
hybridized against itself as well as against the DNAs of the type strains of all species of Cupriavidus. The genomic DNA-DNA hybridization values between strain CPDB6 ${ }^{\mathrm{T}}$ and all Cupriavidus species were, in all cases, less than $30 \%$ (Table 2), thus confirming that strain $\mathrm{CPDB}^{\mathrm{T}}$ could be delineated as a novel species of Cupriavidus.

Cellular fatty acid methyl ester analyses were performed using GC and a standardized protocol similar to that of the MIDI Sherlock MIS system (http://www.ccug.se/pages/ CFA_method_2008.pdf). Prior to cellular fatty acid extraction, strains were grown and harvested under the same conditions using blood agar as the cultivation medium. Cellular fatty acids were identified and quantified and the relative amount of each fatty acid in a strain was expressed as a percentage of the total fatty acids in the profile of that strain and presented in comparison with the type strain of the type species of the genus Cupriavidus ( $C$. necator CCUG $52238^{\mathrm{T}}$ ) and with the type strains of the most closely related species (C. respiraculi CCUG $46809^{\mathrm{T}}$, C. pauculus CCUG $12507^{\mathrm{T}}$ and C. gilardii CCUG $38401^{\mathrm{T}}$ ) (Supplementary Table S1, available in IJSEM Online). The major cellular fatty acids detected in strain $\mathrm{CPDB6}^{\mathrm{T}}$ were hexadecanoic $(16: 0)$ and cis-9-hexadecenoic $(16: 1 \omega 7 c)$ acids, comprising 25 and $30 \%$, respectively, of the total summed cellular fatty acids, as indicated in Supplementary Table S1. The relative amount of tetradecanoic acid (14:0) could be used to differentiate strain $\mathrm{CPDB}^{\mathrm{T}}$ from related Cupriavidus species. Strain $\mathrm{CPDB6}^{\mathrm{T}}$ was also distinguishable from C. respiraculi, C. gilardii and C. pauculus, the closest related species according to 16S rRNA gene sequence comparative analyses, in the relative amounts of summed cis-11-octadecenoic acid $(18: 1 \omega 7 c / 9 t / 12 t)$ (C. respiraculi and $C$. gilardii) and the amounts of cis-9hexadecenoic acid $(16: 1 \omega 7 c)$ and $\Delta$-cis-9,10-methylenehexadecanoic acid (17:0 cyclo) (C. pauculus). The presence of the minor fatty acid iso-C16:0 in strain $\mathrm{CPDB}^{\mathrm{T}}$ was an additional differential characteristic.

Based on genotypic and phenotypic analyses, it is concluded that strain $\mathrm{CPDB}^{\mathrm{T}}$ represents a novel species within the genus Cupriavidus. The name Cupriavidus pampae sp. nov. is proposed.

\section{Description of Cupriavidus pampae sp. nov.}

Cupriavidus pampae [pam'pa.e. N.L. n. pampa (from Quechuan noun pampa) pampa; N.L. gen. n. pampae of pampa, the grassland plains of temperate South America, especially Argentina, where the soil samples were obtained from which the type strain of the species was isolated].

Colonies on R2A agar are 3-4 $\mathrm{mm}$ in diameter, nonpigmented, circular and darker in the centre, with a translucent and undulating margin. Cells are aerobic, Gram-negative, non-fermenting, non-sporulating, motile rods. Growth on R2A agar medium occurs at $10-30{ }^{\circ} \mathrm{C}$. On blood agar medium, good growth is observed at $30{ }^{\circ} \mathrm{C}$; weak growth is observed at $37^{\circ} \mathrm{C}$. Reactions for oxidase and catalase are positive, whereas urease, esterase (C4), lipase, acid phosphatase, $\beta$-galactosidase and $\beta$-glucosidase are negative. No nitrate reduction, indole formation, glucose fermentation or aesculin and arginine dihydrolase activities are observed. D-Glucose, D-gluconate, caprate, adipate, Lmalate, citrate and lactate are assimilated. Trehalose, Larabinose, D-mannose, D-mannitol, $\mathrm{N}$-acetylglucosamine, maltose, sucrose and phenylacetate are not assimilated.

The type strain is $\mathrm{CPDB}^{\mathrm{T}}$ (=CCUG $55948^{\mathrm{T}}=$ CCM-A29:1289 ${ }^{\mathrm{T}}$ ), isolated from soils chronically exposed to phenoxy herbicides in the AHP region, Argentina.

\section{Acknowledgements}

The authors are thankful to F. Flocco, who kindly provided access to soil samples and logistical support for sampling. The authors acknowledge the technical expertise of the CCUG staff for phenotyping and cellular fatty acid analyses. The authors thank J. Euzéby for advice concerning the species epithet. This work was supported by the INCO-DC Program of the European Community, project 'ACCESS' (contract no. ICA4-CT-2002-10011) and Agencia Nacional de Promoción Científica y Tecnológica (Argentina). V.C. and L.M. are fellows of CONICET. M. G. was supported by exchange with the CCUG through fellowships from the Spanish Ministerio de Educación y Ciencia, by means of the José Castillejo Program (2008) and from FEMS Research Fellowship 2009-1. E. R. B.M. acknowledges support from ALF, Västra Götalandsregion, Sweden (project no. LUA-11574) and from Health Canada Agency (project no. 4500118123$)$.

\section{References}

Chen, W.-M., Laevens, S., Lee, T.-M., Coenye, T., De Vos, P., Mergeay, M. \& Vandamme, P. (2001). Ralstonia taiwanensis sp. nov., isolated from root nodules of Mimosa species and sputum of a cystic fibrosis patient. Int J Syst Evol Microbiol 51, 1729-1735.

Coenye, T., Falsen, E., Vancanneyt, M., Hoste, B., Govan, J. R. W., Kersters, K. \& Vandamme, P. (1999). Classification of Alcaligenes faecalis-like isolates from the environment and human clinical samples as Ralstonia gilardii sp. nov. Int J Syst Bacteriol 49, 405-413.

Coenye, T., Goris, J., De Vos, P., Vandamme, P. \& LiPuma, J. J. (2003). Classification of Ralstonia pickettii-like isolates from the environment and clinical samples as Ralstonia insidiosa sp. nov. Int $J$ Syst Evol Microbiol 53, 1075-1080.

Cuadrado, V., Merini, L. J., Flocco, C. G. \& Giulietti, A. M. (2008). Degradation of 2,4-DB in Argentinean agricultural soils with high humic matter content. Appl Microbiol Biotechnol 77, 1371-1378.

EWG (2006). National Tap Water Quality Database. Environmental Working Group. (http://ewg.org)

Felsenstein, J. (1981). Evolutionary trees from DNA sequences: a maximum likelihood approach. J Mol Evol 17, 368-376.

Felsenstein, J. (1989). PHYLIP - phylogeny inference package (version 3.2). Cladistics 5, 164-166.

Goris, J., De Vos, P., Coenye, T., Hoste, B., Janssens, D., Brim, H., Diels, L., Mergeay, M., Kersters, K. \& Vandamme, P. (2001). Classification of metal-resistant bacteria from industrial biotopes as Ralstonia campinensis sp. nov., Ralstonia metallidurans sp. nov., and Ralstonia basilensis Steinle et al. 1998 emend. Int J Syst Evol Microbiol 51, 1773-1782.

Gosselin, R. E., Smith, R. P. \& Hodge, H. C. (1984). Clinical Toxicology of Commercial Products, 5th edn. Baltimore: Williams and Wilkins. 
Hauben, L., Vauterin, L., Swings, J. \& Moore, E. R. B. (1997). Comparison of $16 \mathrm{~S}$ ribosomal DNA sequences of all Xanthomonas species. Int J Syst Bacteriol 47, 328-335.

Hernández, M., Villalobos, P., Morgante, V., González, M., Reiff, C., Moore, E. \& Seeger, M. (2008). Isolation and characterization of a novel simazine-degrading bacterium from agricultural soil of central Chile, Pseudomonas sp. MHP41. FEMS Microbiol Lett 286, 184-190.

HSDB (2005). Hazardous Substances Data Bank. US National Library of Medicine. (http://toxnet.nlm.nih.gov/)

IARC (2003). International Agency for Research on Cancer Monographs. World Health Organization.

INDEC (2002). Censo Nacional Agropecuario. Buenos Aires, Argentina: Instituto Nacional de Estadísticas y Censos.

Johannesen, H. \& Aamand, J. (2003). Mineralization of aged atrazine, terbuthylazine, 2,4-D, and mecoprop in soil and aquifer sediment. Environ Toxicol Chem 22, 722-729.

Makkar, N. S. \& Casida, L. E., Jr (1987). Cupriavidus necator gen. nov., sp. nov.: a nonobligate bacterial predator of bacteria in soil. Int J Syst Bacteriol 37, 323-326.

Marmur, J. (1961). A procedure for the isolation of deoxyribonucleic acid from microorganisms. J Mol Biol 3, 208-218.

Merini, L. J., Cuadrado, V., Flocco, C. G. \& Giulietti, A. M. (2007). Dissipation of 2,4-D in soils of the Humid Pampa region, Argentina: a microcosm study. Chemosphere 68, 259-265.

Merini, L. J., Cuadrado, V. \& Giulietti, A. M. (2008). Spiking solvent, humidity and their impact on 2,4-D and 2,4-DCP extractability from high humic matter content soils. Chemosphere 71, 2168-2172.

Page, R. D. M. (1996). TreeView: an application to display phylogenetic trees on personal computers. Comput Appl Biosci 12, 357-358.

Pearson, W. R. \& Lipman, D. J. (1988). Improved tools for biological sequence comparison. Proc Natl Acad Sci U S A 85, 2444-2448.

Reasoner, D. J. \& Geldreich, E. E. (1985). A new medium for the enumeration and subculture of bacteria from potable water. Appl Environ Microbiol 49, 1-7.

Sahin, N., Isik, K., Tamer, A. U. \& Goodfellow, M. (2000). Taxonomic position of "Pseudomonas oxalaticus" strain Ox1 ${ }^{\mathrm{T}}\left(\mathrm{DSM} 1105^{\mathrm{T}}\right)$ (Khambata and Bhat, 1953) and its description in the genus Ralstonia as Ralstonia oxalatica comb. nov. Syst Appl Microbiol 23, 206-209.

Sato, Y., Nishihara, H., Yoshida, M., Watanabe, M., Rondal, J. D., Concepcion, R. N. \& Ohta, H. (2006). Cupriavidus pinatubonensis sp. nov. and Cupriavidus laharis sp. nov., novel hydrogen-oxidizing, facultatively chemolithotrophic bacteria isolated from volcanic mudflow deposits from Mt. Pinatubo in the Philippines. Int J Syst Evol Microbiol 56, 973-978.

Schop, R. N., Hardy, M. H. \& Goldberg, M. T. (1990). Comparison of the activity of topically applied pesticides and the herbicide 2,4-D in two short-term in vivo assays of genotoxicity in the mouse. Fundam Appl Toxicol 15, 666-675.

Stackebrandt, E. \& Goebel, B. M. (1994). Taxonomic note: a place for DNA-DNA reassociation and $16 \mathrm{~S}$ rRNA sequence analysis in the present species definition in bacteriology. Int J Syst Bacteriol 44, 846849.
Steinle, P., Stucki, G., Stettler, R. \& Hanselmann, K. W. (1998). Aerobic mineralization of 2,6-dichlorophenol by Ralstonia sp. Strain RK1. Appl Environ Microbiol 64, 2566-2571.

Steinle, P., Stucki, G., Stettler, R. \& Hanselmann, K. W. (1999). Ralstonia basilensis sp. nov. In Validation of publication of new names and new combinations previously effectively published outside the IJSB, List no. 71. Int J Syst Bacteriol 49, 1325-1326.

Stevens, J. T. \& Sumner, D. D. (1991). Herbicides. In Handbook of Pesticide Toxicology, vol. 3, pp. 1317-1408. Edited by W. J. Hayes, Jr \& E. R. Laws, Jr. New York, NY: Academic Press.

Thompson, J. D., Gibson, T. J., Plewniak, F., Jeanmougin, F. \& Higgins, D. G. (1997). The CLUSTAL_X windows interface: flexible strategies for multiple sequence alignment aided by quality analysis tools. Nucleic Acids Res 25, 4876-4882.

Urdiain, M., López-López, A., Gonzalo, C., Busse, H. J., Langer, S., Kämpfer, P. \& Roselló-Móra, R. (2008). Reclassification of Rhodobium marinum and Rhodobium pfennigii as Afifella marina gen. nov. comb. nov. and Afifella pfennigii comb. nov., a new genus of photoheterotrophic Alphaproteobacteria and emended descriptions of Rhodobium, Rhodobium orientis and Rhodobium gokarnense. Syst Appl Microbiol 31, 339-351.

US EPA (1992). Pesticides in Ground Water Database: a Compilation of Monitoring Studies: 1971-1991 National Summary. Washington, DC: US Environmental Protection Agency.

Vandamme, P. \& Coenye, T. (2004). Taxonomy of the genus Cupriavidus: a tale of lost and found. Int J Syst Evol Microbiol 54, 2285-2289.

Vandamme, P., Goris, J., Coenye, T., Hoste, B., Janssens, D., Kersters, K., De Vos, P. \& Falsen, E. (1999). Assignment of Centers for Disease Control group IVc-2 to the genus Ralstonia as Ralstonia paucula sp. nov. Int J Syst Bacteriol 49, 663-669.

Vaneechoutte, M., Kämpfer, P., De Baere, T., Falsen, E. \& Verschraegen, G. (2004). Wautersia gen. nov., a novel genus accommodating the phylogenetic lineage including Ralstonia eutropha and related species, and proposal of Ralstonia [Pseudomonas] syzygii (Roberts et al. 1990) comb. nov. Int J Syst Evol Microbiol 54, 317-327.

Walker, M. M. \& Keith, L. H. (1992). EPA's Pesticide Fact Sheet Database. Chelsea, MI: Lewis Publishers.

Wauters, G., Claeys, G., Verschraegen, G., De Baere, T. Vandecruys, E., Van Simaey, L., De Ganck, C. \& Vaneechoutte, M. (2001). Case of catheter sepsis with Ralstonia gilardii in a child with acute lymphoblastic leukemia. J Clin Microbiol 39, 4583-4584.

Weed Science Society of America (1994). Herbicide Handbook, 7th edn. Champaign, IL: Weed Science Society of America.

Yabuuchi, E., Kosako, Y., Yano, I., Hotta, H. \& Nishiuchi, Y. (1995). Transfer of two Burkholderia and an Alcaligenes species to Ralstonia gen. nov.: proposal of Ralstonia pickettii (Ralston, Palleroni and Doudoroff 1973) comb. nov., Ralstonia solanacearum (Smith 1896) comb. nov. and Ralstonia eutropha (Davis 1969) comb. nov. Microbiol Immunol 39, 897-904.

Zahm, S. H., Weisenburger, D. D., Babbitt, P. A., Saal, R. C., Vaught, J. B., Cantor, K. P. \& Blair, A. (1990). A case-control study of nonHodgkin's lymphoma and the herbicide 2,4-dichlorophenoxyacetic acid (2,4-D) in eastern Nebraska. Epidemiology 1, 349-356. 